\title{
FACTORS INFLUENCE THE USE OF THE SYSTEM INFORMATION ACCOUNTING IN SMES IN BANYUMAS DISTRICT
}

\author{
Nurcahyani $^{*}{ }^{*}$, Atiek Sri Purwati ${ }^{1}$, Taufik Hidayat ${ }^{1}$ \\ ${ }^{1}$ Accounting Department, Economic and Business Faculty, Universitas Jenderal Soedirman, Indonesia \\ *Email corresponding author: nurcahyani434@yahoo.com
}

\begin{abstract}
This research is a research in SMES listed in the Department of Cooperatives and SMES District Banyumas. The title of this study "Factors Affecting the Use of Accounting Information System on SMES in Banyumas District". The purpose of this study is to analyse the influence of performance expectations, business expectations, social factors and human resources on the use of accounting information systems. This type of research is quantitative research. The data used is the primary data with the respondent's response source through a distributed questionnaire. Sampling techniques using purposive sampling techniques and samples obtained as much as 100 SMES. Data analysis uses descriptive statistics, data quality tests, the classic assumption tests and multiple linear regression analyses. Results of this study showed variations of changes in the use of accounting information system can be explained by the independent variables for $45.6 \%$ and the results of this research showed that social factors have no effect on increasing use of Accounting information System. Meanwhile, performance expectations, business expectations and human resources have an effect on increasing the use of accounting information systems.
\end{abstract}

Keywords : performance expectations, business expectations, social factors, human resources, use of accounting information systems, SMES.

\section{INTRODUCTION}

Small and Medium Enterprises (UKM) is one sector that is able to make a major contribution to the country, especially in income. Based on data from the Ministry of Cooperatives (Kemenkop) and UKM, at the end of 2017 revenues from the business sector in Indonesia amounted to Rp 7.005 .950 billion or around $62,58 \%$ of the total national GDP. If calculated based on business scale, the distribution of income contribution from the business sector is equal to $38,90 \%$ of microenterprises, amounting to $9,73 \%$ of small businesses, and $13,95 \%$ of the contribution of mediumsized businesses. Until now, the number of small businesses in Indonesia is 716.8 thousand units and medium enterprises are 65,5 thousand units.

The development of small and medium enterprises (UKM) which is quite good at this time is inseparable from the problems that are still experienced by SMEs in running their businesses. These problems are related to the management of information in financial that are still not considered by UKM owners. These problems are related to the management of information in financial terms that are still not considered by UKM owners.

In this regard, small and medium enterprises need improvement in terms of managing information as a new form of strategy. One strategy that can be applied to improve information management is by using an accounting information system.

Banyumas District is an area that has a good UKM development. Compared to other regions in Central Java, Banyumas District has a more significant business development and increases a lot every year. Based on data from the Dinas Koperasi and SMEs (UKM Dinkop) in Banyumas District until the period 2017, the number of small businesses in Banyumas was 1.776 units, while the number of medium businesses was 25 units.

Research conducted by Atiek Sri Purwati, Irianing Suparlinah and Negina Kencono Putri (2014) entitled "The Use of Accounting Information in the Business Decision Making Process on Small and Medium Enterprises in Banyumas District, Indonesia" shows that SME accounting 
information is related to financial statements and business conditions are needed by external parties, in this case BPR as an investment channeling institution. Accounting information made by SMEs is needed by the BPR to be used as a basis for consideration in accepting or rejecting investment proposals. In fact, the majority of respondents from BPR said that the accounting information made by SMEs was not in accordance with the applicable accounting standards, so that the BPR had not been able to accept the submission of investment from SMEs.

The use of accounting information systems in SMEs can be influenced by several factors such as performance expectations, business expectations, social factors and human resources. Performance expectations are the beliefs of users when using accounting information systems performance will increase (Ardi, 2010). Other factors that can influence the use of accounting information systems are business expectations. Business expectations show how much the individual's level of confidence in the ease of use of the system can minimize individual thoughts and efforts (Krismadinata et al., 2018).

Social factors also become one of the factors that can influence the use of accounting information systems. Social factors represent the magnitude of the influence of the environment around the individual which will influence individuals to do something (Krismadinata et al., 2018). Other factors that can influence the use of accounting information systems are human resources. According to Sofyan (2015) human resources are people who are employed as drivers to achieve organizational goals. The availability of accounting information systems must be supported by human resources who have the ability to manage them.

This research using Theory of Planned Behavior (TPB). TPB is a theory that emphasizes rationality that comes from behavior or individual behavior and individual beliefs on the basis of individual awareness. This behavior does not only depend on one's will, but there are also factors that are not in the individual's control, such as the availability of resources and opportunities to prove the behavior (Ajzen, 2005).

Based on Law Number 20 of 2008 the definition of Small and Medium Enterprises is: 1) Small-scale business is a stand-alone productive economic enterprise, carried out by individuals or business entities that are not subsidiaries or not branches of companies that are owned, controlled, or become part of either directly or indirectly from Medium or Large Businesses that meet the following criteria : a) Having a minimum net worth of Rp. 51.000.000,00 - Rp. $500.000 .000,00$ excluding land and building of business premises, b) Has annual sales of more than Rp. 300.000.000,00 - Rp. 2.500.000. 000,00; 2) Medium-sized businesses are productive economic businesses that are independent, carried out by individuals or business entities that are not subsidiaries or branches of companies owned. Mastered, or become part of either directly or indirectly with Small or Large Businesses with the amount of net assets or annual sales proceeds as regulated in this Act. The criteria for this Medium Business are: a) Having a net worth of more than Rp. 500.000.000,00 - Rp 10.000.000.000,00 excluding land and buildings of business premises, b) Has annual sales of more than Rp. 2.500.000.000,00 up to a maximum of Rp.50.000.000.000,00.

According to Warren (2006) there are three types of companies that can generate profits, namely, manufacturing companies, trading companies and service companies. Accounting information system according to Bodnar \& Hopwood (2010) is a collection of various kinds of resources in the form of humans and equipment that functions to convert financial data into information for users. Performance expectations are the level of one's belief that the use of a system will help them improve their performance (Hamzah, 2010). Performance expectations are related to how high the individual's trust by using the system can help him gain profits (job fit) from the actions taken. With the involvement of individual systems, they believe that in carrying 
out work responsibilities, the process will be easier and the results are in line with expectations.

Business expectations are the level of one's belief in the ease of use of the system which will reduce a person's efforts in doing his work (Krismadinata et al., 2018). Business expectations are related to the level of complexity of the work performed. The higher the level of complexity of the work that must be done, the higher the individual's willingness to use the system with the terms of the system can help solve complex work. In addition to complexity, perceived ease is also related to business expectations. The availability of flexible information systems and guidelines for implementing them can certainly help increase individual willingness.

Social factors are a level where someone assumes that another person assures himself that he must do something (Krismadinata et al., 2018). Social factors can arise from the environment around the business location, for example the influence of fellow business owners, superiors and coworkers. If other business owners around it have used accounting information systems and their output can help the owner in running a business that is more effective and efficient and results in improved performance, it will motivate businesses to use the information system. The increasingly complex job responsibilities provided by managers can also encourage individuals to use the system.

Human resources are one of the important factors that determine the development of the company. In essence, human resources in the form of humans are employed in an organization as a driver to reach the organization (Sofyan, 2015). Therefore, human resources must be managed properly to improve the effectiveness and efficiency of the organization. A system that is applied in a business without being supported by the existence of human resources capable of driving the system will not work according to its function. These resources need to be trained continuously in order to be able to improve their performance.

The purpose of this research is to analyze the effect of performance expectations on the use of accounting information systems in SMEs in Banyumas Regency, analyze the effect of business expectations on the use of accounting information systems in SMEs in Banyumas Regency, analyze the influence of social factors on the use of accounting information systems in SMEs in Banyumas Regency and analyze the effect of human resources on the use of accounting information systems in SMEs in Banyumas Regency.

The results of this study can be used to add references related to the use of accounting information systems in SMEs and as a reference for further research. In practical benefit, the results of this research can be used as input for related agencies such as Desperindagkop to determine procedures and make appropriate policies and motivate business actors to use accounting information systems in business management.

\section{LITERTURE REVIEW}

Performance expectations are a belief that an individual has when using an information system can help them perform better and can be done effectively and efficiently. This concept is related to the individual's perception that using the system will benefit. The benefits referred to are related to better performance by the existence of a system. Performance expectations are closely related to perceived usefulness. In the research conducted by Venkatesh and Davis (2000), the results support that perceived usefulness is the dominant factor that drives individuals to use the system. Performance expectations are a manifestation of attitude toward behavior in the theory of planned behavior. Performance expectations indicate an interest in better performance results with the use of accounting information systems. Higher confidence to produce better performance with the use of accounting information systems can increase the use of these systems to assist individuals in managing their business. Research conducted by Rosita (2013) shows that 
performance expectations have a significant positive effect on the use of information systems. The results of these studies are different from the research conducted by Wedha (2013) which states that performance expectations do not have a positive effect on interest in utilizing accounting information systems. Based on the description above, the research hypothesis can be formulated as follows:

H1: Performance expectations affect the use of accounting information systems.

Business expectations are the level of confidence possessed by individuals when using information systems can alleviate the effort that must be made by individuals, especially in terms of time and effort. The expectations of individuals with the use of accounting information systems can help individuals to carry out business management activities in a shorter period of time without requiring more energy. This concept is related to the level of ease of the system used. The availability of information systems that are flexible and in accordance with the complexity of the work will be easily accepted because there is no need for too large a business. to use the system. The factor of business expectations is the embodiment of attitude toward behavior as one component in the theory of planned behavior. The ease of accounting information systems will ease the effort that must be made by individuals in completing work. Individual beliefs that are increasingly increasing the ease of use of accounting information systems can encourage individuals to use accounting information systems. Previous research conducted by Triyas (2016) states that business expectations affect the interest in using information systems. While the results of the research conducted by Christinawati (2016) show that business expectations do not affect the interest in using information systems. Based on the description above, the following hypothesis can be formulated:

H2: Business expectations affect the use of the accounting information systems.

Social factors are encouragement from the surrounding environment that can come from fellow business owners, colleagues and managers. In addition, the government can also be one of the parties that can provide incentives for businesses to use the system. Other parties who have used the system and can show better results in their efforts can motivate business owners to use the system.

Social factors indicate how much the level of individual confidence that other people can convince individuals to use the system. Someone will be easily attracted and follow when seeing other people feel the benefits of the system that has been used. Venkatesh et.al (2003) states that social factors have a direct influence on the use of accounting information systems by individuals that are represented through subjective norms. Subjective norm as one component in the theory of planned behavior is the level of individual beliefs that are formed from the influence of the environment around the individual. The greater the influence of the environment around the individual can encourage individuals to use accounting information systems. The results of Triyas's study (2016) state that social factors influence the interest in using accounting information systems. The results of different studies were conducted by Christinawati (2016) which states that social factors have no effect on interest in utilizing information systems. Based on the explanation above, the research hypothesis can be formulated as follows:

H3: Social factors influence the increasing use of accounting information systems.

Human resources are one of the important factors in the process of running a business because they are the drivers and determinants of policies and decisions to achieve organizational goals (Sofyan, 2015). The ability of human resources to be able to carry out financial management using the system can determine the success of using the system and can advance the business being run. The ability of human resources to be able to use the system can be obtained through the process of training, education and experience gained. Human resources are representations 
of perceived behavior control in the theory of planned behavior. This perception is related to the presence or absence of resources and the ability of individuals in the use of accounting information systems. Accounting information systems can run effectively or not depending on how human resources they have can use them. No matter how sophisticated a system that can be held to support a business if it is not supported by qualified human resources and has the ability to support it, the system will not produce the information needed. Quality and capability of human resources can influence the use of accounting information systems. Previous research conducted by Wahyu (2015) shows that human resources affect work ability. While the research conducted by Arisonaldi (2013) shows that the quality of human resources has no significant effect on performance. Based on the description above, the following hypothesis can be formulated:

H4: Human resources affect the use of accounting information systems.

\section{RESEARCH METHODOLOGY}

\section{Population and Sampling Technique}

This type of research is survey research with a quantitative approach. The study was conducted in Banyumas District, Central Java Province. The population in this study were SMEs included in the criteria used in the study. Based on data from the Office of Cooperatives and SMEs (Diskop UKM) in Banyumas District, the number of SMEs in Banyumas District until 2017 was recorded at 1.776 small businesses and 25 medium-sized businesses.

The sample in this study is the owner or manager of SMEs in Banyumas District. The sample in this study was chosen based on the purposive sampling method. The criteria for SMEs used in this study are: (a) Small and medium enterprises have been registered with the Cooperative and SME Office in Banyumas District. (b) Having administrative or financial staff. (c) Having a manager or owner of a company that is still actively serving. This type of research is survey research with a quantitative approach.

\section{Data Analysis Technique}

The stages of data analysis in this study include validity and reliability testing, descriptive statistics, classic assumption tests including normality test, multicollinearity test and heteroscedasticity test. Then the accuracy test of the model using $F$ test, coefficient of determination test, and hypothesis testing using multiple regression analysis.

\section{RESULTS AND DISCUSSION}

Table 1. Sample Data of Small and Medium Enterprises

\begin{tabular}{clccc}
\hline No & $\begin{array}{l}\text { Type of } \\
\text { Business }\end{array}$ & $\begin{array}{c}\text { Total } \\
\text { (unit) }\end{array}$ & $\begin{array}{c}\text { Business } \\
\text { Scale }\end{array}$ & $\begin{array}{c}\text { Total } \\
\text { (unit) }\end{array}$ \\
\hline 1 & Manufacturing & 6 & Small & 95 \\
2 & Trading & 75 & Medium & 5 \\
3 & Services & 19 & & 100 \\
\hline Total & & 100 & & \\
\hline
\end{tabular}

\section{Data Quality Test}

Based on the results of the normality test and reliability test all item statements and research instruments are said to be valid and reliable where each item statement $r$ count is greater than the rtabel as much as 0.374 . For the reliability test results all the research instruments were reliable with the Cronbach Alpha coefficient of greater than 0.60 . 


\section{Normality Test}

Based on the data normality test output, it can be seen that the asymp value. sig. (2-tailed) from the Kolmogorov-Smirnov $\mathrm{Z}$ test for standardized residual variables is 0,650 , which means that it is greater than the value $(0,05)$, so it can be concluded that the data used are normally distributed.

\section{Multicollinearity test}

The Variance Inflation Factor (VIF) test output in appendix 8 shows that the VIF value and tolerance of performance expectation variables (X1), business expectations (X2), social factors (X3) and human resources (X4) are smaller than 10 and tolerance value> 0,1 so it can be concluded that there is no multicollinearity in the regression model.

\section{Heteroscedasticity Test}

Based on heteroscedasticity test output, it can be seen that the significance value of the test of performance expectation variable (X1), business expectation variable (X2), social factor variable (X3) and human resource variable (X4) are greater than the value $(0,05)$ So it can be concluded that there is no heteroscedasticity in the regression model.

\section{Model Accuracy Test}

Test the accuracy of the model in this study using the F test. Based on the test results Fcount of 21,512 is greater than the value of Ftable with $\mathrm{df}=(5-1)$ and (100-5) which is 2,45 and the Sig value of $0,000<0,05$. These results show evidence that the regression model formed in this study was declared significant or appropriate with the research data (goodness of fit).

\section{Determination Coefficient Test}

The adjusted $R$ square value shows a number of 0,456 . The coefficient shows that a $45,60 \%$ variation in the variable use of accounting information systems in SMEs in this study can be explained by changes in variables, while $54,40 \%$ can be explained by other variables not included in the regression model.

Hypothesis Analysis

Table 2. Multiple Linear Regression Analysis

\begin{tabular}{llll}
\hline Independent Variable & $\begin{array}{l}\text { Coefficient } \\
\text { Regression }\end{array}$ & $\mathrm{t}$ - value & Sig. \\
\hline Performance expectations & 0,294 & 4,031 & 0,000 \\
Business expectations (X2) & 0,260 & 3,162 & 0,002 \\
Social Factors (X3) & 0,122 & 1,553 & 0,124 \\
Human Resources (X4) & 0,224 & 3,153 & 0,002 \\
\hline Constant & $=3,342$ & & \\
Adj R Square & $=0,456$ & & \\
F-value & $=21,512$ & & \\
F-table & $=2,45$ & & \\
Sig. F & $=0,000$ & & \\
\hline
\end{tabular}

Testing the First Hypothesis: Performance expectations affect the use of accounting information systems. The value of $t$-count in the performance expectation variable is 4,031 which is greater than the value of $t$-table 1,6606 and the significance of $0,000<0,05$. The results of these statistical tests prove that partially the performance expectation variables have a positive and 
significant effect on the use of accounting information systems in SMEs. Thus, the first hypothesis which states that performance expectations affect the increase in use of accounting information systems is accepted.

Testing of the Second Hypothesis: Business expectations affect the use of accounting information systems. The value of the performance expectation variable t-count is 3,162 greater than the value of $t$-table 1,6606 and the significance of $0,002<0,05$. The test results show that partially the business expectation variables have a positive and significant effect on the use of accounting information systems in SMEs. Thus, the second hypothesis which states that business expectations affect the use of accounting information systems is accepted.

Testing of the Third Hypothesis: Social factors influence the increase in the use of accounting information systems.The t-count of social factor variables 1,553 is smaller than the value of t-table 1,6606 and the significance of $0,124>0,05$. The results of these statistical tests prove that partially social factor variables have a negative and insignificant effect on the use of accounting information systems in SMEs. Thus, the third hypothesis which states that social factors influence the increase in the use of accounting information systems in SMEs is rejected.

Testing of the Fourth Hypothesis: Human resources affect the use of accounting information systems.The value of t-count variable human resource 3,153 is greater than the value of t-table 1,6606 and the significance of $0,002<0,05$. The test results show that partially the human resource variables have a positive and significant effect on the use of accounting information systems in SMEs. Thus, the fourth hypothesis which states that human resources affect the increase in the use of accounting information systems in SMEs is accepted.

\section{DISCUSSION}

The first hypothesis which states that performance expectations influence the increase in use of accounting information systems is accepted. The higher the level of performance expectations of SMEs, it can increase the use of accounting information systems in SMEs. Expansion of performance is the level of one's belief that the use of a system will help them improve their performance (Hamzah, 2010). Based on Appendix 5 descriptive statistics, the average SME actor has sufficient understanding of performance expectations. This is reinforced by the frequency of respondents' answers which shows that the majority of SMEs in Banyumas District have a perception that accounting information system can help SMEs in managing information well and can improve their performance.

The results of this study are in accordance with Theory of Planned Behavior (TPB) related to the component of attitude toward behavior that originates from the behavioral believe. Performance expectations represent behavioral believe, which means that individuals believe they can improve their performance with the use of accounting information systems. This result is also in accordance with the research conducted by Rosita (2013) and Triyas (2016) which proves that performance expectations have a positive and significant effect on the use of accounting information systems. Siska's research (2014) also states that performance expectations have a positive effect on the use of accounting information systems. The results of the Wedha study (2013) state different things, namely performance expectations are not 
positively related to interest in using information systems. The real situation of the respondents from PERUM Bulog Central Java Regional Division employees shows that the information system is a new thing to implement so that it still needs adjustments in applying it. It takes great effort to be able to implement information systems properly because of changes in habits so that employees are not sure they can improve their performance by using information systems.

The second hypothesis states that business expectations affect the use of accounting information systems. The higher business expectations of SME owners can increase the use of accounting information systems in SMEs. According to Krismadinata, et al., (2018) business expectations are the level of one's belief in the ease of use of the system which will reduce a person's efforts in doing their work. Based on Appendix 5 descriptive statistics, the average respondent has sufficient understanding of business expectations. This is reinforced by the frequency of respondents' answers which shows that the majority of SMEs in Banyumas District have confidence that the use of accounting information systems is easily understood and applied.

The results of this study are in accordance with one component of Theory of Planned Behavior that is attitude toward behavior that originates from the behavioral believe. The business expectation factor represents a behavioral believe which means that individuals believe that they will be able to minimize individual efforts related to energy and time used to complete the work with the use of accounting information systems. This result is in accordance with the research conducted by Rosita (2013) and Dennys (2018) which states that there is a positive influence between business expectations and the use of accounting information systems. These results contradict the research of Yunita and Wahyu Meiranto (2014) which states that there is no positive relationship between business expectations and interest in using accounting information systems. The use of the required information system for some employees of PT. Pertamina (Persero) Region IV is not based on the willingness of the relations of each individual so as not to create a sense of comfort. This situation causes information system users to feel less effective in completing work using information systems.

The third hypothesis which states that social factors influence the use of accounting information systems is rejected. The higher the encouragement of social factors does not influence the increase in the use of accounting information systems. Social factors are the level at which someone considers other people to be able to convince themselves that they must do something (Krismadinata et al., 2018). Referring to Appendix 5, descriptive statistics, the average UKM actor understands enough about the existence of social factors. Statistical testing of hypotheses shows that there is no influence between social factors and the use of accounting information systems. This can be interpreted that SMEs are not influenced by the existence of surrounding social factors in making decisions to use accounting information systems.

The influence of social factors in the environment around SMEs in Banyumas District which 
includes the influence of colleagues and organizations around individuals in the form of encouragement, direction, assistance and assessment in the use of accounting information systems is not felt by SMEs. The social influences felt by SMEs are only about marketing and profitable business opportunities. In addition, SMEs in Banyumas District assume that the involvement of the accounting information system in the process of running a business is based on two things, they are their own willingness and ability without any influence from the surrounding environment. SMEs in Banyumas District have not been able to use accounting information systems due to limited capital and lack of access to information related to their use. In addition, the level of activity of SMEs in the process of running a business is also a factor that causes them not to use accounting information systems. This causes SMEs do not have time to use accounting information systems even though they feel they need them to help completing their work and do good management. This is the reason for the existence of social factors that do not affect SMEs to use accounting information systems.

This research is not in accordance with the Theory of Planned Behavior as one of the factors that drives individuals to do something. Social factors that are representations of subjective norms in the form of encouragement from the environment around the individual were not successfully proven in this study. The results of this study are not in line with Wedha's research (2013) which states that social factors have a positive effect on the interest in using information systems. Respondents who came from the Central Java Regional Division BULOG employees of the Regional Office felt that there was a social influence in the form of coercion from the Board of Directors of the National Logistics Agency to master and use information systems. The demands of making reports online and real time, make employees who are responsible as operators of each division must use information systems. Research conducted by Christinawati (2016) and Drajat (2016) shows the same results, that there is no influence between social factors and the use of accounting information systems.

The fourth hypothesis which states that human resources have an effect on increasing use of accounting information systems is accepted. Human resources that have the capacity in the form of the level of knowledge, skills, expertise, experience and competency in carrying out the functions of accounting information systems in the business management process encourage SMEs to use accounting information systems.

Human resources are one of the important factors in determining the development of a company because the essence of human resources is humans who are employed in a company or organization that has a duty as a driver to achieve the organizational goals that have been set (Sofyan, 2015). Based on attachment 5, namely descriptive statistics, the average respondent understands the competence of human resources. This is supported by the frequency of respondents' answers which shows that the majority of SMEs in Banyumas District already have 
the capacity of human resources to use accounting information systems.

The results of this study are in accordance with the Theory of Planned Behavior related to the components of perceived behavior control derived from control believe. Factors of human resources are representations of control believe as a form of belief that there are factors that facilitate individuals in the use of accounting information systems. This research is also in accordance with the results of Nur Fuad et al .'s research which states that the quality of human resources has a positive and significant effect on the performance of cooperatives and research in Wahyu (2015) which states that there is an influence between human resources and work ability in this regard related to system use accounting information. It is different from Arisonaldi's (2013) study which states that the quality of human resources does not have a significant effect on the performance of SKPD. The selection of respondents from the Head of the SKPD and the Head of Financial Subdivision as the party most responsible for financial management at the SKPD causes the data obtained to be inaccurate so that it cannot represent all staff of financial staff who are under it. The lack of seriousness in responding to respondents' statements and understanding also resulted in bias in the results of this study.

\section{CONCLUSION}

Performance expectations affect the use of accounting information systems in SMEs in Banyumas District. This shows that SMEs have confidence in being able to improve their performance with the use of accounting information systems. The higher the level of confidence to be able to perform better performance the higher the use of accounting information systems.

Business expectations affect the use of accounting information systems in SMEs in Banyumas District. This shows that SMEs have confidence that accounting information systems are easy to use and can reduce the efforts of SMEs in terms of energy and time to complete their work. The higher the level of confidence in the ease of use of accounting information systems the higher the use of accounting information systems.

Social factors have no effect on increasing the use of accounting information systems in SMEs in Banyumas District. This is because coworkers and organizations around SMEs do not provide direction, encouragement, assistance or assessment related to the use of accounting information systems. In addition, SMEs think that the involvement of the accounting information system in the process of carrying out their business is based on two things, they are their own willingness and ability without any influence from the environment around SMEs.

Human resources influence the increase in the use of accounting information systems in SMEs in Banyumas District. Through experience and training that have been followed by SMEs, SMEs understand the functions and roles of accounting information systems and have the competence and ability to use accounting information systems to help in work completion. 


\section{IMPLICATION}

For SMEs, it is expected to pay attention to performance expectations, business expectations and human resources in order to increase the use of accounting information systems.

For the Office of Cooperatives and SMEs, they are expected to conduct training on the use of accounting information systems to help SMEs to improve their business management.

\section{LIMITATIONS OF RESEARCH}

This study uses a closed questionnaire so that the answers obtained are less detailed. Further research can use open questionnaires to obtain respondents' answers in more detail.

The independent variables in this study were only able to explain the dependent variable at $45,60 \%$, while the remaining $54,40 \%$ was explained by other variables that not used in this study. Future studies are expected to add other variables so that they can explain more deeply what factors influence the use of accounting information systems in SMEs.

The majority of SMEs who are respondents in this study are of the type of trading business so that information obtained from other types of businesses is still lacking. Future research is expected to be able to share questionnaires evenly across various types of businesses so that the information obtained is more complete and can represent respondents' answers from each type of UKM.

\section{REFERENCES}

Adawiyah, W. R. (2011). Faktor Penghambat Pertumbuhan Usaha Mikro Kecil Menengah ( UMKM ): Studi di Kabupaten Banyumas, 1-18Jurnal Ekonomi, Universitas Jendral Soedirman.

Agung P., Dennys., Erbabley., Agustinus Fritz Wijaya. (2018). Analisis Penerapan Teknologi Informasi pada Perusahaan Manufaktur menggunakan Teori Adopsi Teknologi Informasi Unified Theory of Acceptance and Use a Technology (UTAUT).Jurnal Sistem Informasi Indonesia (JSI). Vol.3, No.1.

Ajzen, I. (2005). Attitudes, personality, behavior. Milton Keynes: Open University Press.

----r- $£ 2005)$. Laws of human behavior: Symmetry, compability, and attitude behavior correspondence. Multivariate research strategies. Achen, Germany: Shaker Verlag.

Amalia, Siska Kartika. (2014). Faktor-Faktor Yang Mempengaruhi Penggunaan Sistem Informasi Akuntansi (Studi pada Universitas Swasta di Kota Bandung Yang Menggunakan SIA). Jurnal Akuntansi. Universitas Pendidikan Indonesia.

Amin, K. (2012). PERMASALAHAN UKM. Di akses dari: kangaminblog.blogspot.com/2012/12/permasalahan-ukm.html.

Andrianto Elvin. (2017). Pengaruh Kapasitas Sumber Daya Manusia, Pemanfaatan Teknologi Informasi, Dan Sistem Pengendalian Intern Pemerintah Terhadap Kualitas Laporan Keuangan Pemerintah Daerah Dengan Komitmen Organisasi Sebagai Variabel Moderasi (Studi Empiris Pada Satuan Kerja Perangkat Daerah Di Kabupaten Sleman). Skripsi. Sarjana Akuntansi Universitas Negeri Yogyakarta.Yogyakarta. (Dipublikasikan). Dikutip dari : 
https://eprints.uny.ac.id/50988/

Ayutika Riza D.N. (2013). Faktor-Faktor Yang Mempengaruhi Kepuasan Pemakai Sistem Informasi Akuntansi Keuangan Pada Dinas Perhubungan Kabupaten Ponorogo. Skripsi. Sarjana Akuntansi Universitas Muhammadiyah Ponorogo. (Dipublikasikan). Dikutip dari: https://eprints.umpo.ac.id/745/

Azriani, N. R., Subroto, B., \& Baridwan, Z. (2013). Minat Keperilakuan Individu Menggunakan Piranti Lunak sebagai Penunjang Pelaporan Keuangan. Jurnal Akuntansi Multiparadigma, $4(3), 402-416$.

Christinawati,. (2016) Pengaruh ekspektasi kinerja, usaha, faktor sosial serta kondisi yang memfasilitasi terhadap minat memanfaatkan sistem informasi (penelitian empiris pada organisasi nirlaba di Surabaya). Undergraduate thesis, Widya Mandala Catholic University Surabaya. Dikutip dari: repository.wima.ac.id/8072/

Dinas Koperasi dan UKM Purwokerto. (2017). Jumlah UKM semua Sektor di Kabupaten Banyumas. Purwokerto.

Dosenit.com. 2015. Pengertian Sistem Informasi. Diakses dari:

https://

dosenit.com/kuliah-it/sistem-informasi/pengertian-sistem-informasi-akuntan si-menurutpara-ahli.

Ermayanti Dwi. (2009). Sistem Informasi Akuntansi. Diakses dari: https://dwiermayanti.wordpress.com/2009/10/13/sistem-informasi-akuntan si/

Fiddin, F., Kamaliah, \& Hardi. (2013). Faktor-Faktor yang Mempengaruhi Minat Pemanfaatan Sistem Informasi dan Penggunaan Sistem Informasi (Studi Pada Satuan Kerja Perangkat Daerah Pemerintah Provinsi. Jurnal SOROT, 8(1), Hal. 77-94.

Firdaus., Nadirsyah., Heru Fahlevi. (2015). Pengaruh Kualitas Sumber Daya Manusia, Pemanfaatan Teknologi Informasi dan Penerapan Kebijakan Akuntansi Terhadap Kualitas Laporan Keuangan Pemerintah Kota Banda Aceh. Jurnal Magister Akuntansi . Pascasarjana Universitas Syiah Kuala.Vol.4, No.1, Hal.45-54.

Fuad, Nur., Adolfina., Irwan Trang. (2017). Pengaruh Kualitas Sumber Daya Manusia dan Daya Saing Terhadap KInerja Organisasi (Studi Pada Koperasi Anugrah Mega Mandiri Manado). Jurnal EMBA. Vol.5, No.2, Hal. 1653-1663.

Ghozali, Imam. (2009). "Teori, Konsep dan Aplikasi dengan SPSS 17". Semarang : UNDIP.

Groedu Software. (2017). Mengembangkan Bisnis Ukm (Usaha Kecil Menengah)/Umkm Dengan Software Akuntansi. Diakses dari:

https://softwareaccountingsurabaya.com/2017//12/08/mengembangkan-bis nis-ukmusaha-kecil-menengahumkm-dengan-software-akuntansi.

Hamzah, Ardi. 2010. Faktor-Faktor Pemakai yang Mempengaruhi Minat Pemanfaatan Sistem Informasi. Jurnal Akuntansi Paradigma, Vol.1, No.2 